Sultan Qaboos University Journal of Arts \& Social Sciences
جامعة السلطان قابوس الإسلوداب

مجلة الآداب والعلوم الاجتمانعية

\title{
English Supervisors' Perspectives of Supervision in Omani Public Schools
}

\begin{tabular}{c}
\hline Rahma Al-Mahrooqi \\
\hline Deputy Vice-Chancellor for Postgraduate \\
Studies and Research \\
Sultan Qaboos University, Oman \\
mrahma@squ.edu.om
\end{tabular}

\begin{tabular}{c}
\hline C. J. Denman \\
\hline Office of the Deputy Vice-Chancellor \\
for Postgraduate Studies and \\
Research \\
Sultan Qaboos University, Oman \\
denman@squ.edu.om
\end{tabular}




\title{
English Supervisors' Perspectives of Supervision in Omani Public Schools
}

\author{
Rahma Al-Mahrooqi and C. J. Denman
}

\section{Abstract:}

The current study examined English supervisors' perspectives of supervision in Omani public schools through the administration of a three-part, 13-category Likert-scale questionnaire. The questionnaire was distributed as part of a larger nation-wide investigation to 48 English supervisors in Omani schools and was completed by 35 participants. Areas examined included participants' views of the supervisory process, including its effectiveness, supervisor roles and qualifications, challenges and opportunities for professional development, and the contributions supervision makes to teacher development. The questionnaire also explored participant engagement in a series of steps before, during, and after supervisor observation. Mixed attitudes about the supervisory process were reported, although a number of important concerns were raised about the way English supervision occurs in Omani government schools.

Keywords: Oman; English; Supervision; Basic Education; EFL

\section{آراء مشرفي اللّخة الإنجليزية حول الإشراف في المدارس الحكومية العُمانية}

\author{
رحمة المحروقي وكرستيان دينمان
}

الملخص:

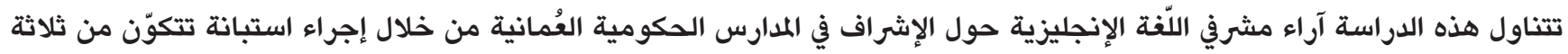

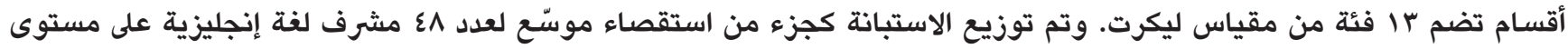

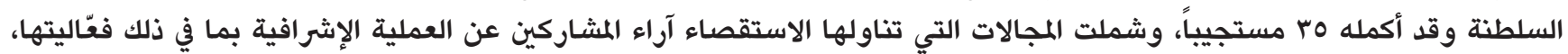

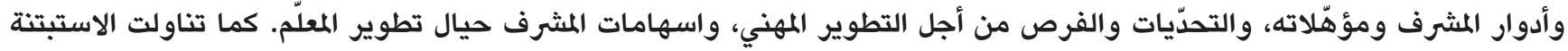

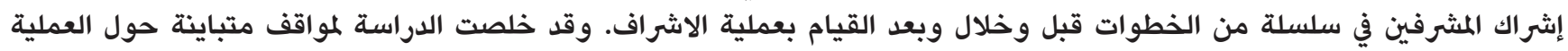

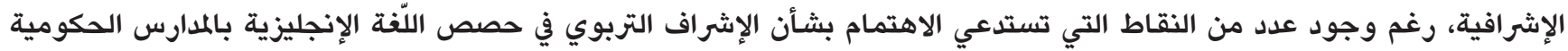

الكلمات المفتاحية: سلطنة عُمان؛ اللّة الإنجليزية؛ الإشراف؛ التعليم الأساسي؛ اللّة الإنجليزية كلغة أجنبية (EFL) 


\section{Introduction.}

Since the introduction of a formal education system in Oman in 1970, the public school curriculum has undergone a number of important reforms. The most recent of these was the introduction of the Basic Education curriculum, which was designed to support the development of higher-order thinking skills in learner-centred environments that address learners' physical, affective, social, and intellectual development (Ministry of Education, 2001).

In the Basic Education system, the English language was identified as one of the core subjects to be emphasized. To achieve this, students started learning the language from grade 1 , as opposed to grade 4 under the General Education system, and received 659 additional hours of instruction in the subject than were previously available. Moreover, since inadequate teacher training was highlighted by a World Bank study as a potential area of concern, the Ministry of Education cooperated with the UK's University of Leeds to upgrade English teachers' qualifications from diplomas to BAs in TESOL (Teaching English to Speakers of Other Languages). The program lasted from 1998 to 2008, and qualified around 1,060 teachers. As a result, most English teaching jobs in the country, and especially those in Cycle One of Basic Education (grades 1-4), are now held by Omanis.

More importantly for the sake of the current paper, however, was the expansion in Basic Education of a supervision system in which English teachers are observed and mentored by supervisors employed by the Ministry of Education in order to provide professional development opportunities and to evaluate teachers through observations, postobservation meetings, and oral and written feedback about how to improve their teaching practice (Al-Abri, 2009). In addition, supervisors are also responsible for providing and/or recommending potentially beneficial workshops for teachers, conducting teamteaching with teachers in order to develop their practical classroom skills, and for keeping teachers abreast of the latest developments in the field.

However, despite the positive intent of this supervisory system, a number of teachers and supervisors have claimed that they do not believe the system works in an effective and fair manner (see Al-Mahrooqi, Al-Maamari, \& Denman, 2015). For these reasons, the current research, building upon the work of AlMahrooqi, Denman and Al-Maamari (2016) and AlMahrooqi and Denman (2017), was one of the first empirical studies to explore supervisors' perspectives of the English school supervision system in the Sultanate of Oman. It did this through administering a three-part, 13-category Likert-scale questionnaire to English supervisors throughout the country in academic year 2012/2013.

\section{Literature Review.}

After Sultan Qaboos ascended the throne in 1970, one of the top priorities of the new government was the provision of publically-funded education for all citizens. The implementation of a nation-wide education system was so successful that, by 2008 , the number of schools in Oman had reached 1,300 and the number of students was 600,000 (46\% of whom were female) with over 43,000 teachers - a dramatic increase from the two or three public schools with around 900 male students in the country before 1970. Adding to these, there has also been a boom in the number of private institutions in Oman, with around 50,000 students in 400 private schools.

Having achieved the goal of providing access to free education at the school level, the Ministry of Education has more recently turned its attention to the quality of education provided. The Ministry of Education (2006) perhaps forecast the necessity of this drive for quality by highlighting the finding of a number of UNESCO/UNICEF studies which revealed "lower than expected student achievement levels" ( $p$. 97) among Omani learners in addition to deficiencies in facilities, resources, and, most importantly here, teacher training. Similar findings calling for reform emerged from the 1990 UN Jomtien Conference and 2000's Dakar Framework for Action which both raised the question of education quality in the sultanate. Adding weight to these reports, internal pressure came from views expressed in the government policy document "Vision for Oman's Economy - Oman 2020" which stressed the role that education must play in the country's economy for the 21st century. Oman wants to participate fully in the global economy, but, faced with impending natural resource exhaustion (Chapman, Al Barwani, \& Amin, 2009), it needs an adaptable national workforce to help maintain its progression. Education has been identified at official levels as essential in achieving this.

Despite the extensive nature of these reforms and the amount of time and resources that have been devoted to fully and effectively implementing them, the Basic Education reform has not yet produced anticipated results. In fact, Omani school students' achievement in general remains below average with, 
in 2003-2004, the Canadian company Canedcom International, which tested 7,700 grade 4 students in Arabic, English, mathematics and science, reporting that Omani Basic Education students were generally one year behind international standards. In fact, the Ministry of Education (2006, pp. 112-113) states that, "Compared to international norms, there were approximately three times as many students in Oman with difficulties in reading."

The Oman Ministry of Education has accepted that there needs to be input into teaching practices from people working outside schools themselves. Its report "Education in Oman: The drive for quality" (2012) stated that, "Discussions with focus groups and with senior MOE [Ministry of Education] personnel suggest that there should be greater input from other stakeholders, especially those with extensive teaching experience" (Ministry of Education and the World Bank, 2012, p. 93). According to Barber, Mourshed and Whelan (2007, p. 45), the Ministry of Education, the Directorates of Education, and public schools need "a transparent performance-management system to ensure that students learn the right knowledge and skills, that teachers perform well, and that schools are properly managed."

Discussions the researchers have had with supervisors and teachers around the country suggest that the system may be emphasizing the wrong goals. That is, schools care about how many of their students go into university and so a culture of studying to pass the test and testing students on factual information remains prevalent. In this environment, some schools may even overlook cheating so as to achieve good outcomes in terms of the number of passing students who could join the prestigious and publically-funded Sultan Qaboos University (SQU) or other public higher education institutions.

In addition, systems for planning and oversight, administration and management, and support and evaluation need to be enhanced. Usually planning is not done on time, and when plans are made, they are not disseminated or well-communicated to all the concerned stakeholders. For example, many people have heard of the Education Strategy/Policy 2040, but very few have actually seen it. The Ministry of Education, the Ministry of Higher Education, and Sultan Qaboos University, despite their common concern with improving the quality of education, work separately, and policies are not shared. Because of this situation, the policies of these institutions may be contradictory and/or duplicate each other.
Al-Jardani (2012) states that the Department of Curriculum Evaluation was founded in Oman in 2005 with the main purpose of participating in the ongoing development and evaluation of the new curriculum in relation to specified learning objectives, learner and societal needs, and the needs of the workforce. In order to carry out this evaluation, Al-Jardani states each year the curriculum section for each subject area nominates the grade level which they would like the Department of Curriculum Evaluation to focus on. The department then asks for feedback from school supervisors, curriculum officers, and subject area teachers, and analyses this with the results of a primary document analysis approach employed by educational researchers working within the department itself.

Moreover, there may also be an over-concern with following procedures and policies. Schools want to adhere to, and comply with, ministry requirements. Teachers want to finish the curriculum and get their papers in order. This is, according to Barber et al. (2007, p. 45), because school inspections generally scrutinize (and therefore reward) administrative performance rather than academic outcomes. A school managed by a principal who rigidly adheres to official policies gets full marks, even if the teaching is mediocre. A school run by a brilliant but less organized principal will be penalized, even if the quality of teaching is high.

In addition to the work of the Department of Curriculum Development, in 2002 the Ministry of Education established a department for educational supervision to offer technical aid to educators through a method of continuous follow-up. Other responsibilities that the department was assigned responsibility for included overseeing the effective implementation of the supervisory system, ensuring that syllabuses are implemented correctly, analysing supervisor reports, and determining teacher needs and how these can be met by training and professional development opportunities (UNESCO World Data on Education, 2011).

The Ministry of Education's in-service training programs also focus on the effectiveness of supervision through the provision of the Advanced Educational Supervision Course. This course aims to assist supervisors in acquiring administrative, technical and supervision efficiencies that enhance their effectiveness as supervisors. This is a one-year course which consists of practical field activities, workshops, and seminars. The trainees are awarded 
an education supervision certificate when all course requirements have been met.

However, anecdotal evidence and the findings of a nation-wide investigation into the reasons why Omani school students often graduate with inadequate English skills (Al-Mahrooqi, Al-Maamari, \& Denman, 2015) suggest that teachers and supervisors believe that the current supervision system for English teachers in Omani public schools has a number of deficiencies that hamper its effective implementation. As of yet, little to no research has focused upon this issue in a systematic way. The current study, therefore, seeks to overcome this through an examination of Omani school English class supervisors' perceptions of the supervisory process through the administration of a three-part, thirteen-category questionnaire.

\section{Methodology}

\subsection{The Sample}

48 supervisors were recruited for a nationwide investigation into the teaching of English in schools in Oman and were involved in 6 distinct research phases involving different data collection instruments. The current paper reports the results of one of these phases, with 35 supervisors completing the questionnaire section with sufficient data to be included. The sample was collected through a process of snowball sampling, with each supervisor who initially agreed to join the study after assurances of anonymity and after being reminded of its voluntary nature, then offering the names of 2-3 more potential participants who were also contacted and asked to participate with the same information and assurances. The resultant sample for this study phase consisted of 35 participants, $68.8 \%$ of whom were males and $31.2 \%$ were females.

The remaining demographic details reported here feature a large amount of missing data, with this perhaps being due to the fact that previous questionnaires supervisors had completed as part of the wider investigation elicited similar information. $4.2 \%$ of the participants were between the ages $22-$ $29,35.4 \%$ between the ages 30-39, 37.5\% between the ages $40-49$ and $16.7 \%$ above 49 years. More than half of the participants (52.1\%) were Omanis, $10.4 \%$ were Egyptians, $4.2 \%$ were Algerian, $2.1 \%$ were Sudanese, and $2.1 \%$ were Indian. Participants were drawn from across Omani, including Dhofar (29.2\%), Al-Dakhilia (20.8\%), Al-Dhahira (12.5\%), Muscat (10.4\%), Al-Wusta (10.4\%), Al-Sharqiya North (6.3\%), Al-Buraimi (4.2\%), and Al-Batinah South (2.1\%). 31.3\% of the sample had between 1-3 years of experience as supervisors, $27.1 \%$ had between $4-6$ years experience, $22.9 \%$ had between $7-9$ years, $10.4 \%$ of them had between $10-12$ years of experience, while only $8.3 \%$ had been supervising for more than 12 years. The majority of the participants (60.4\%) supervised in government Basic Education schools while 18.8\% supervised in General Education schools.

\subsection{The Questionnaire \& Analysis}

Participants were administered a questionnaire that explored their perceptions of the supervisory process. The questionnaire contained three main sections and 13 categories. The first section elicited participants' demographic information, the second explored their views of the supervision process, while the final section required participants to indicate the frequency with which they engaged in a series of steps before, during and after supervision.

The researchers constructed the questionnaire categories and items based on the literature and on informal discussions about potentially problematic areas of supervision with a number of supervisors throughout the country. After constructing the questionnaire, it was sent to four external evaluators who were professors at Oman's only public university but who were not involved in the study itself. The validation process produced a revised version of the instrument which was then administered to participants. Participants were given the choice of the English and Arabic language versions of the questionnaire.

Descriptive analysis, with a focus on item and category means and standard deviations, was conducted for parts two and three of the questionnaire. Cronbach alpha reliability coefficients were calculated to determine the internal consistency of the questionnaire categories. For nine of the 10 categories on part two of the questionnaire, Cronbach alpha coefficients ranged from 0.64 to 0.89 , with an average of 0.80 . However, for the category regarding participants' contributions as supervisors to the professional development of supervised teachers, the Cronbach alpha coefficient was 0.52 which indicates a weak level of internal consistency. This category has been retained here due to the exploratory nature of the study, although the authors acknowledge that results emerging from it need be interpreted with a high degree of caution. For the categories from part 3 of the questionnaire, Cronbach alpha coefficients ranged from 0.68 to 0.83 with an average coefficient 
value of 0.76

\section{Results}

To assist in interpreting item and category means, the following values were assigned to each response category for the second part of the questionnaire based on approximately 0.79 increments between each value:

- Strongly Agree:

$1.00-1.79$

- Agree:

$1.80-2.59$

- Neutral:

2.60-3.39

- Disagree:

$3.40-4.19$

- Strongly Disagree: $4.20-5.00$

Items that have been reverse-scored to maintain scoring consistency across questionnaire categories are marked with an asterisk. Overall means for each of category are:

Supervisors' Views on the Effectiveness of Supervision $-2.50$

Supervisors' Views about Contributions of Supervision to their professional Growth -2.62

Supervisors' Views about Colleagues in the Profession $-2.87$

Challenges Facing Supervisors in the Current Supervision System - 2.95

Supervisors' Professional Role -3.03

Table 1: Supervisors' views on the effectiveness of supervision

\begin{tabular}{|l|c|c|}
\hline \multicolumn{1}{|c|}{ Item } & Mean & Std. Deviation \\
\hline $\begin{array}{l}\text { Has written criteria to assess } \\
\text { teaching performance. }\end{array}$ & 2.26 & 0.98 \\
\hline $\begin{array}{l}\text { Relies on valid criteria. } \\
\begin{array}{l}\text { Focuses on major issues rather } \\
\text { than on unimportant details. }\end{array}\end{array}$ & 2.31 & 1.08 \\
$\begin{array}{l}\text { Clearly defines the role of } \\
\text { supervision and supervisors. }\end{array}$ & 2.37 & 1.08 \\
\hline $\begin{array}{l}\text { Consolidates teachers' } \\
\text { strengths. }\end{array}$ & 2.37 & 1.01 \\
$\begin{array}{l}\text { Defines instructional problems. } \\
\text { Acknowledges teachers' } \\
\text { strengths. }\end{array}$ & 2.44 & 1.08 \\
\hline $\begin{array}{l}\text { Helps solve instructional } \\
\text { problems. }\end{array}$ & 2.54 & 1.01 \\
\hline $\begin{array}{l}\text { Evaluates and measures } \\
\text { classroom activities fairly. }\end{array}$ & 2.57 & 1.04 \\
\hline $\begin{array}{l}\text { Has trained me well on using } \\
\text { the observation criteria. }\end{array}$ & 2.79 & 1.03 \\
\hline $\begin{array}{l}\text { Helps find solutions for } \\
\text { instructional problems. }\end{array}$ & 2.91 & 1.01 \\
\hline \begin{tabular}{l} 
Category Mean \\
\hline
\end{tabular} & 2.50 & 1.01 \\
\hline
\end{tabular}

EFL Supervisors' General View of Current Supervision $-3.04$

Opportunities for Supervisors' Professional Development -3.08

Supervisors' Perceptions of the Supervision Approach $-3.09$

Contributions as a Supervisor to the Professional Development of Supervised Teachers -3.25

Supervisors' Administrative Role - 3.49

The questionnaire category that received the lowest overall response mean, hence indicating more favourable participant attitudes, was supervisors' views on the effectiveness of supervision ( $M=2.50$ ) (see Table 1). Supervisors agreed with eight of the 11 items here, including that supervision "has written criteria to assess teaching performance" ( $M=2.26)$ and "relies on valid criteria" ( $M=2.31)$. Participants also agreed that supervision "focuses on major issues rather than on unimportant details" ( $M=$ 2.33) and "clearly defines the role of supervision and supervisors" ( $M=2.37)$, while also acknowledging $(\mathrm{M}=2.54)$ and consolidating $(\mathrm{M}=2.37)$ "teachers' strengths". The final two items participants agreed with were that the supervisory approach both "defines instructional problems" ( $M=2.44)$ and "helps solve instructional problems" ( $M=2.57)$. However, despite this, supervisors were neutral about whether supervision "helps find solutions for instructional problems" ( $M=2.91)$. Finally, they were also neutral about whether supervision "evaluates and measures classroom activities fairly" ( $M=2.66)$ and "has trained me well on using the observation criteria" ( $M=2.79)$. Table 2 contains items related to the questionnaire category of supervisors' views about contributions of supervision to their teachers' professional growth ( $M$ $=2.62$ ). Participants agreed with six of these items, including that supervision "has encouraged teachers to acquire new knowledge to improve their teaching" $(M=1.97)$, "has introduced teachers to best practices in teaching" ( $M=2.27)$ and "has encouraged teachers to get more training in using new teaching methods and strategies" ( $M=2.38)$. They also agreed that the supervisory process "has given teachers insight into how to motivate their students" ( $M=2.42$ ), even though they were neutral about whether teachers experienced any increases in motivation themselves - "increases teachers' motivation to work hard" (M $=2.66)$ and "improves teachers' morale" ( $M=2.87)$. Supervisors agreed that their supervision "has helped utilize teachers' strengths to enhance their teaching" $(\mathrm{M}=2.30)$ and "provides teachers with educational 
leadership" ( $\mathrm{M}=2.55)$. However, despite this, they remained neutral about whether the process "has contributed to teachers' professional growth" ( $M=2.64)$, "has helped teachers to discover their shortcomings" ( $M=2.70)$, and "has improved teachers' teaching skills and strategies" $(M=3.06)$. The final item supervisors agreed with from this questionnaire category was that supervision "has given teachers constructive feedback on the tests they create and their assessment procedures" ( $M=2.47)$.

Supervisors were neutral in response to the remaining category items, including those relating to identifying and dealing with instructional issues such as "guides teachers in problem-solving related to instructional matters" ( $M=2.63)$, "has encouraged teachers to think of alternatives to solve problems and tackle instructional challenges" ( $M=2.97)$, and "has helped teachers to overcome instructional problems" ( $\mathrm{M}=$ 3.00). Finally, supervisors were neutral about whether supervision "has provided teachers with ideas on how to integrate technology in their teaching" ( $M$ = 2.67) and "provides educational materials that assist teachers in teaching their classes" ( $M=2.78)$.

Table 3 indicates that supervisors were neutral about the qualities and characteristics of their colleagues in the profession ( $M=2.87$ ). That is, they were neutral about all positively-worded items here, including whether their fellow supervisors were "well trained" ( $M=2.68)$, "cooperative" $(M=2.71)$, and "successful in their roles" $(\mathrm{M}=2.94)$. They were also neutral about whether their colleagues "have at least an MA degree" ( $M=2.79$ ) and "are well qualified" ( $M$ $=2.84$ ), while also neither agreeing nor disagreeing about whether they "have very good mentoring skills" ( $M=2.79$ ) and "perform their work professionally" $(M=2.81)$. They were also neutral about whether their fellow supervisors "know English well" ( $\mathrm{M}$ = 2.91). Participants also expressed neutral attitudes in response to the two negatively-worded items about whether their fellow supervisors are "like controllers" ( $\mathrm{M}=3.13$ ) or "like judges" ( $\mathrm{M}=3.18)$.

Like the previous questionnaire category, supervisors were neutral in response to all items regarding the challenges facing supervisors in the current supervision system ( $\mathrm{M}=2.95)$. Table 4 demonstrates that participants remained neutral about all negativelyscored items from this category, including whether, "Supervision is more concerned with administrative issues than with teaching and learning" ( $M=2.67)$ and, "Supervisors have to perform technical tasks (e.g. test and curriculum design) without having
Table 2: Supervisors' views about contributions of supervision to teachers' professional growth

\begin{tabular}{|c|c|c|}
\hline Item & Mean & Std. Deviation \\
\hline $\begin{array}{l}\text { Has encouraged teachers to } \\
\text { acquire new knowledge to } \\
\text { improve their teaching. }\end{array}$ & 1.97 & 1.02 \\
\hline $\begin{array}{l}\text { Has introduced teachers to best } \\
\text { practices in teaching. }\end{array}$ & 2.27 & 0.84 \\
\hline $\begin{array}{l}\text { Has helped utilize teachers' } \\
\text { strengths to enhance their } \\
\text { teaching. }\end{array}$ & 2.30 & 0.95 \\
\hline $\begin{array}{l}\text { Has encouraged teachers to } \\
\text { get more training in using new } \\
\text { teaching methods and strate- } \\
\text { gies. }\end{array}$ & 2.38 & 1.02 \\
\hline $\begin{array}{l}\text { Has given teachers insight into } \\
\text { how to motivate their students. }\end{array}$ & 2.42 & 1.03 \\
\hline $\begin{array}{l}\text { Has given teachers construc- } \\
\text { tive feedback on the tests they } \\
\text { create and their assessment } \\
\text { procedures. }\end{array}$ & 2.47 & 1.02 \\
\hline $\begin{array}{l}\text { Provides teachers with educa- } \\
\text { tional leadership. }\end{array}$ & 2.55 & 1.09 \\
\hline $\begin{array}{l}\text { Guides teachers in problem- } \\
\text { solving related to instructional } \\
\text { matters. }\end{array}$ & 2.63 & 1.04 \\
\hline $\begin{array}{l}\text { Has contributed to teachers' } \\
\text { professional growth. }\end{array}$ & 2.64 & 0.99 \\
\hline $\begin{array}{l}\text { Increases teachers' motivation } \\
\text { to work hard. }\end{array}$ & 2.66 & 1.00 \\
\hline $\begin{array}{l}\text { Has provided teachers with } \\
\text { ideas on how to integrate tech- } \\
\text { nology in their teaching. }\end{array}$ & 2.67 & 1.29 \\
\hline $\begin{array}{l}\text { Has helped teachers to discover } \\
\text { their shortcomings. }\end{array}$ & 2.70 & 0.98 \\
\hline $\begin{array}{l}\text { Provides educational materials } \\
\text { that assist teachers in teaching } \\
\text { their classes. }\end{array}$ & 2.78 & 1.01 \\
\hline $\begin{array}{l}\text { Has encouraged teachers to } \\
\text { reflect on their teaching. }\end{array}$ & 2.82 & 0.98 \\
\hline Improves teachers' morale. & 2.87 & 0.99 \\
\hline $\begin{array}{l}\text { Has encouraged teachers to } \\
\text { think of alternatives to solve } \\
\text { problems and tackle instruc- } \\
\text { tional challenges. }\end{array}$ & 2.97 & 0.95 \\
\hline $\begin{array}{l}\text { Has helped teachers to over- } \\
\text { come instructional problems. }\end{array}$ & 3.00 & 1.03 \\
\hline $\begin{array}{l}\text { Has improved teachers' teaching } \\
\text { skills and strategies. }\end{array}$ & 3.06 & 1.12 \\
\hline Category Mean & 2.62 & 1.02 \\
\hline
\end{tabular}

received adequate training" ( $M=2.70)$. They were also neutral about whether, "Supervisors do not have enough professional development opportunities" ( $M=2.87$ ) and if, "Supervisors are given insufficient freedom and flexibility in their work by the ministry" 
Table 3: Supervisors' views about colleagues in the profession

\begin{tabular}{|l|c|c|}
\hline \multicolumn{1}{|c|}{ Item } & Mean & Std. Deviation \\
\hline Are well trained. & 2.68 & 1.40 \\
\hline Are cooperative & 2.71 & 1.32 \\
\hline Have at least an MA degree. & 2.79 & 1.01 \\
\hline Have very good mentoring skills & 2.79 & 1.36 \\
\hline Perform their work profession- & 2.81 & 1.22 \\
ally. & 2.84 & 1.13 \\
\hline Are well qualified & 2.91 & 0.95 \\
\hline Know English well. & 2.94 & 1.09 \\
\hline Are successful in their roles. & 3.13 & 1.02 \\
\hline Are like controllers. ${ }^{*}$ & 3.18 & 0.85 \\
\hline Are like judges. ${ }^{*}$ & 2.87 & 1.13 \\
\hline Category Mean & &
\end{tabular}

Table 4: Challenges facing supervisors in the current supervision system

\begin{tabular}{|l|c|c|}
\hline \multicolumn{1}{|c|}{ Item } & Mean & Std. Deviation \\
\hline $\begin{array}{l}\text { Supervision is more concerned } \\
\text { with administrative issues than } \\
\text { with teaching and learning. }\end{array}$ & 2.67 & 1.19 \\
$\begin{array}{l}\text { Supervisors have to perform } \\
\text { technical tasks (e.g. test and } \\
\text { curriculum design) without } \\
\text { having received adequate } \\
\text { training. }\end{array}$ & 2.70 & 1.19 \\
\hline $\begin{array}{l}\text { Supervisors do not have enough } \\
\text { professional development } \\
\text { opportunities.* }\end{array}$ & 2.87 & \\
$\begin{array}{l}\text { Supervisors are given } \\
\text { insufficient freedom and } \\
\text { flexibility in their work by the } \\
\text { ministry. }\end{array}$ & 2.94 & 0.99 \\
\hline $\begin{array}{l}\text { Supervisors receive little } \\
\text { support from the directorate. }\end{array}$ & 2.97 & 1.37 \\
$\begin{array}{l}\text { Supervisors sometimes do not } \\
\text { receive sufficient support from } \\
\text { school administrations.* }\end{array}$ & 3.00 & 1.40 \\
\hline $\begin{array}{l}\text { Supervisors have to travel } \\
\text { to remote schools, which } \\
\text { decreases their motivation to } \\
\text { do their job properly. }\end{array}$ & 3.14 & 1.44 \\
$\begin{array}{l}\text { Supervisors have to supervise } \\
\text { a big number of teachers, } \\
\text { which makes it difficult to } \\
\text { offer sufficient guidance for } \\
\text { teachers.* }\end{array}$ & 3.15 & 1.06 \\
\hline $\begin{array}{l}\text { Supervisors' work is hindered } \\
\text { by the limited resources (e.g., } \\
\text { not having common rooms or } \\
\text { transport). }\end{array}$ & 3.18 & \\
Category Mean & & \\
\hline
\end{tabular}

$(M=2.94)$. Supervisors neither agreed nor disagreed about the level of support they receive - "Supervisors receive little support from the Directorate" ( $M=2.97)$ and, "Supervisors sometimes do not receive sufficient support from School administrations" ( $M=3.00$ ), while also being neutral about whether, "Supervisors have to travel to remote schools, which decreases their motivation to do their job properly" ( $M=3.14$ ) and, "Supervisors have to supervise a big number of teachers, which makes it difficult to offer sufficient guidance for teachers" $(M=3.15)$. Finally, participants remained neutral about whether their, "Supervisors' work is hindered by the limited resources (e.g., not having common rooms or transport)" ( $M=3.18)$.

Table 5 indicates that participants agreed with two items from the questionnaire category of supervisors' professional role $(M=3.03)$. That is, they agreed that, "I give the teacher feedback on tests before they are administered" ( $M=2.44)$ and, "I offer teachers useful and constructive feedback based on the observation sessions I conduct" ( $M=2.56)$. However, supervisors were neutral in response to eight of the remaining items, including about whether, "I engage in discussing teaching practices with teachers" ( $M=2.62)$ and, "I convey teachers' opinions related to English teaching to the upper authorities in the Directorate/Ministry" (M $=2.91$ ). . They were also neutral about whether, "I make teachers aware of the criteria used in supervision" (M $=2.73$ ) and, "I create language teaching observation forms" ( $M=3.03)$. Supervisors neither agreed nor disagreed with the items, "I give the teacher feedback on tests before they are administered" ( $M=2.82$ ) and, "I examine language learning tasks available in textbooks in order to produce better tasks" ( $\mathrm{M}=$ 3.03), while also being neutral about whether, "I run follow-up observation visits to find out if my feedback has been taken into account by teachers" ( $M=3.18$ ) and if "overall, I conduct supervision to help teachers improve in their teaching practices" ( $M=3.30)$. Participants disagreed with three of the items from this questionnaire category. That is, they did not agree that they "respond to teachers' instructional concerns and challenges" ( $M=3.41$ ), "make sure that senior teachers at school are doing their job properly" $(M=3.68)$, and "train teachers on how to create a language-teaching portfolio that demonstrates the teacher's professional development" $(M=3.71)$. Supervisors expressed neutral attitudes about all items related to their general views of current supervision $(M=3.04)$ (see Table 6). They expressed neutrality in response to the only negatively-worded item from 
this category - "Supervision is mostly for paperwork formalities and regulations" ( $M=2.63)$. However, they were also neutral about all positively-worded items, including whether supervision "is necessary to maintain teaching quality" ( $M=2.86)$, "evaluates teachers fairly" ( $M=2.91)$, and "can be considered as a means for teacher professional development" $(M=3.26)$. Supervisors also remained neutral about whether the supervisory process is "inspiring" ( $M=$ 3.15), "useful" ( $M=3.23$ ), and "adequately serves teachers' needs" ( $M=3.29$ ).

Table 7 indicates that, like the previous questionnaire category, supervisors remained neutral about their opportunities for professional development $(\mathrm{M}=$ 3.08). For example, they were neutral about whether, "I conduct research (theoretical and/or action research) on areas related to teaching/supervision" ( $\mathrm{M}=2.80$ ) and, "I write journals/diaries related to language teaching" ( $M=2.94)$. They were also neutral about whether they had the opportunity to benefit from further training - "I receive hands-ontraining on how to conduct effective supervision" ( $M=2.91$ ) and, "I am sent to attend presentations/ workshops on new supervision issues" ( $M=3.24$ ). Supervisors expressed neutral attitudes about the possibilities of discussing issues related to supervision with others, as witnessed in means for the items, "I get the opportunity to discuss effective approaches to supervision" ( $M=3.00)$, "I get the opportunity to discuss challenges of supervision related matters" ( $M=3.15)$, and, "I get the opportunity to discuss solutions for supervision problems" ( $M=3.39$ ), even though this final item mean was close to the neutral/ disagree cut-off point. Finally, supervisors were neutral about whether they engaged in self-reflection - "I reflect on my supervision sessions to improve as a supervisor" ( $M=3.03$ ) and, "The insights I get from observing teaching helps me improve my supervision" $(\mathrm{M}=3.33)$.

Table 8 features the items related to the questionnaire category of supervisors' perceptions of the supervision approach ( $M=3.09)$. Participants again expressed neutral attitudes in response to both negatively- and positively-worded items here, including whether supervision "creates fear and stress in teachers" ( $M=$ 2.76), "creates stress in supervisors" ( $M=2.94)$, and "creates fear and stress in students" ( $M=2.97)$. They were also neutral about whether supervision "is done with the aim of control, rather than improvement" $(M=2.76)$, "is like a mentoring relationship" $(M=$ 3.18), and "is inspection rather than a collaborative
Table 5: Supervisors' professional role

\begin{tabular}{|c|c|c|}
\hline Item & Mean & Std. Deviation \\
\hline $\begin{array}{l}\text { I give the teacher feedback } \\
\text { on tests before they are } \\
\text { administered. }\end{array}$ & 2.44 & 1.35 \\
\hline $\begin{array}{l}\text { I offer teachers useful and } \\
\text { constructive feedback based } \\
\text { on the observation sessions I } \\
\text { conduct. }\end{array}$ & 2.56 & 1.13 \\
\hline $\begin{array}{l}\text { I engage in discussing teaching } \\
\text { practices with teachers. }\end{array}$ & 2.62 & 1.21 \\
\hline $\begin{array}{l}\text { I make teachers aware of the } \\
\text { criteria used in supervision }\end{array}$ & 2.73 & 1.13 \\
\hline $\begin{array}{l}\text { I give the teacher feedback } \\
\text { on tests before they are } \\
\text { administered. }\end{array}$ & 2.82 & 1.19 \\
\hline $\begin{array}{l}\text { I convey teachers' opinions } \\
\text { related to English teaching to } \\
\text { the upper authorities in the } \\
\text { directorate/ministry. }\end{array}$ & 2.91 & 1.10 \\
\hline $\begin{array}{l}\text { I examine language learning } \\
\text { tasks available in textbooks in } \\
\text { order to produce better tasks. }\end{array}$ & 3.03 & 1.16 \\
\hline $\begin{array}{l}\text { I create language teaching } \\
\text { observation forms. }\end{array}$ & 3.03 & 1.17 \\
\hline $\begin{array}{l}\text { I run follow-up observation } \\
\text { visits to find out if my feedback } \\
\text { has been taken into account by } \\
\text { teachers. }\end{array}$ & 3.18 & 1.17 \\
\hline $\begin{array}{l}\text { Overall, I conduct supervision to } \\
\text { help teachers improve in their } \\
\text { teaching practices. }\end{array}$ & 3.30 & 1.02 \\
\hline $\begin{array}{l}\text { I respond to teachers' } \\
\text { instructional concerns and } \\
\text { challenges. }\end{array}$ & 3.41 & 0.82 \\
\hline $\begin{array}{l}\text { I make sure that senior teachers } \\
\text { at school are doing their job } \\
\text { properly. }\end{array}$ & 3.68 & 1.04 \\
\hline $\begin{array}{l}\text { I train teachers on how to create } \\
\text { a language-teaching portfolio } \\
\text { that demonstrates the teacher's } \\
\text { professional development. }\end{array}$ & 3.71 & 0.97 \\
\hline Category Mean & 3.03 & 1.11 \\
\hline
\end{tabular}

process" ( $M=3.34)$. Supervisors expressed neutrality about whether supervision "includes sharing mutual responsibilities and participation between the teacher and the supervisor" ( $M=2.94)$ and "is top down: instructions come from supervisor to teacher" ( $M=3.21)$, in addition to the closely-related items regarding whether the process is "authoritarian" (M $=3.24$ ) or "democratic" ( $M=3.36)$. Supervisors were neutral about whether supervision "is more or less 'looking for errors"' ( $M=2.94)$, and whether it "does not assess class dynamics/interaction" ( $M=3.00$ ) and "does not focus enough on the discourse that 
Table 6: EFL supervisors' general view of current supervision

\begin{tabular}{|l|c|c|}
\hline \multicolumn{1}{|c|}{ Item } & Mean & Std. Deviation \\
\hline $\begin{array}{l}\text { Supervision is mostly for } \\
\text { paperwork formalities and } \\
\text { regulations. }\end{array}$ & 1.06 & 1.06 \\
$\begin{array}{l}\text { Supervision is necessary to } \\
\text { maintain teaching quality. }\end{array}$ & 1.33 & 1.33 \\
\hline $\begin{array}{l}\text { Supervision evaluates teachers } \\
\text { fairly. }\end{array}$ & 0.95 & 0.95 \\
$\begin{array}{l}\text { Supervision is inspiring for } \\
\text { teachers. }\end{array}$ & 1.02 & 1.02 \\
\hline $\begin{array}{l}\text { Supervision is useful for } \\
\text { teachers. }\end{array}$ & 1.52 & 1.52 \\
$\begin{array}{l}\text { Supervision can be considered as } \\
\text { a means for teacher professional } \\
\text { development. }\end{array}$ & 1.12 & 1.12 \\
\hline $\begin{array}{l}\text { Supervision adequately serves } \\
\text { teachers' needs. }\end{array}$ & 1.43 & 1.43 \\
\hline \begin{tabular}{l} 
Category Mean \\
\hline
\end{tabular}
\end{tabular}

Table 7: Opportunities for supervisors' professional development

\begin{tabular}{|l|c|c|}
\hline \multicolumn{1}{|c|}{ Item } & Mean & Std. Deviation \\
\hline $\begin{array}{l}\text { I conduct research (theoretical } \\
\text { and/or action research) on areas } \\
\text { related to teaching/supervision. }\end{array}$ & 2.80 & 1.16 \\
$\begin{array}{l}\text { I receive hands-on-training } \\
\text { on how to conduct effective } \\
\text { supervision. }\end{array}$ & 2.91 & 1.52 \\
\hline $\begin{array}{l}\text { I write journals/diaries related to } \\
\text { language teaching. }\end{array}$ & 2.94 & 1.00 \\
\hline $\begin{array}{l}\text { I get the opportunity to } \\
\text { discuss effective approaches to } \\
\text { supervision. }\end{array}$ & 3.00 & 1.19 \\
\hline $\begin{array}{l}\text { I reflect on my supervision } \\
\text { sessions to improve as a } \\
\text { supervisor. }\end{array}$ & 3.03 & 1.20 \\
\hline $\begin{array}{l}\text { I get the opportunity to discuss } \\
\text { challenges of supervision related } \\
\text { matters. }\end{array}$ & 3.15 & 1.02 \\
\hline $\begin{array}{l}\text { I am sent to attend } \\
\text { presentations/workshops on new } \\
\text { supervision issues. }\end{array}$ & 3.24 & 1.26 \\
$\begin{array}{l}\text { The insights I get from observing } \\
\text { teaching helps me improve my } \\
\text { supervision. }\end{array}$ & 3.33 & 1.24 \\
\hline $\begin{array}{l}\text { I get the opportunity to discuss } \\
\text { solutions for supervision } \\
\text { problems. } \\
\text { Category Mean }\end{array}$ & 3.39 & 1.19 \\
\hline
\end{tabular}

takes place in the classroom (i.e. focuses mostly on the teacher)" ( $M=3.03$ ). Finally, respondents were neutral about whether the supervisory approach "does not concern itself with teacher-made tests" $(M=3.21)$, "does not establish connections between different observations" ( $M=3.21$ ), and "does not concern itself with extra-curricular activities that can enhance students' English language learning" ( $M=$ 3.30).

Table 9 indicates that participants were predominantly neutral about the majority of items related to the questionnaire category of contributions as a supervisor to the professional development of the teachers you supervise $(M=3.25)$. For instance, they were neutral about whether they train teachers "to create supplementary materials that assist them in teaching their classes" ( $\mathrm{M}=2.85)$ and "on how to motivate students to improve their English language" $(M=2.89)$. They were also neutral about whether, "When giving feedback, I offer teachers alternative English teaching practices to improve their teaching" $(M=3.03)$, "I encourage teachers to teach in a way that is consistent with the principles of reflective teaching" ( $M=3.06)$, and, "Overall, I help teachers improve in their profession" ( $M=3.06)$. Supervisors expressed neutral attitudes about whether they encourage attendance at, and even offer themselves, workshops for teachers - "I encourage teachers to attend courses, workshops or sessions to become better teachers" ( $M=3.09$ ) and, "I run courses for teachers to help them acquire new knowledge and to get more training in using new teaching methods and strategies" ( $M=3.35)$. Participants remained neutral about whether they "encourage teachers to work together for effective teaching" ( $M=3.09$ ) and "help teachers think critically about their English teaching practices" ( $M=3.24)$.

The final items from this category that respondents were neutral about regraded whether they "train teachers to think of alternatives to solve problems and tackle instructional challenges relevant to their contexts" ( $M=3.12$ ) and "provide teachers with resources that can improve language teaching (e.g. websites, tips for teaching, and books)" ( $M=3.21$ ). Despite this level of neutrality, respondents disagreed with the item, "I encourage teachers to reflect on their teaching practices following class observations" $(M=3.50)$. They also disagreed about whether they provide guidance to teachers "on how to improve their language proficiency" ( $M=3.19)$ and "to teachers related to English teaching" ( $M=4.18)$.

Table 10 indicates that supervisors displayed neutral attitudes to about half of the six items related to their administrative role $(M=3.49)$. That is, they were 
neutral about whether they contribute to "penalizing irresponsible teachers" ( $\mathrm{M}=2.74)$ or "to rewarding teachers with best practices" $(M=3.21)$. They also displayed neutral attitudes about whether, "I make sure that teaching resources are available for teachers" $(M=3.33)$. However, they disagreed about whether, "I update the teacher with the new regulations and criteria established by the Ministry/Directorate" ( $M=$ 3.76) and their multiple responsibilities "reduces my focus on supervision's main functions" ( $M=4.12)$. Finally, supervisors also disagreed about whether, "Supervisors play a role in teachers' recruitment" (M = 3.79).

The third part of the questionnaire asked participants to indicate the frequency with which they engaged in a number of steps before, during and after supervision. Response means here are interpreted as:

$\begin{array}{ll}\text { - Never: } & 1.00-1.79 \\ \text { - Rarely: } & 1.80-2.59 \\ \text { - Sometimes: } & 2.60-3.39 \\ \text { - Often: } & 3.40-4.19 \\ \text { - Always: } & 4.20-5.00\end{array}$

Table 11 indicates that supervisors only often engaged in two of the listed activities prior to observation. That is, the items, "When the observation focuses on a specific aspect of teaching (e.g., class management, use of visual aids, etc.), I tell the teacher what the focus is" ( $M=3.81)$ and, "I decide everything in relation to the observation process on my own" ( $M=3.74)$, both fell within the often response range. However, participants claimed that they only sometimes "notify the teacher of the observation criteria" ( $M=3.10)$, "inquire about the characteristics of the class and the lesson to be observed" ( $M=3.03$ ), and "inform the teacher about the purpose of the observation (i.e. evaluation, promotion, etc.)" ( $\mathrm{M}=2.74)$. Moreover, supervisors state that sometimes "There is a set schedule for my visits and observations" ( $M=2.90$ ) and that they only sometimes "meet with the teacher to discuss their professional concerns, expectations and problems" ( $\mathrm{M}=2.83)$.

Unlike activities before the observation, participants claimed that they either often or always engage in all activities listed in Table 12 during the observation process. For example, supervisors claimed that the observation duration was always "adequate to assess the teacher's performance fairly" $(M=4.45)$ and that they always "participate in the lesson I observe in a collegial manner" ( $M=4.35)$. However, despite this, supervisors acknowledged that, "My presence in the classroom as an observer worries the teacher" ( $\mathrm{M}=$
4.32). Respondents also claimed that they always "fill out an observation form" ( $M=4.32$ ), "take notes to document the observation for subsequent discussion" $(M=4.29)$, and "sit at the back and do not intervene in the lesson at all" $(M=4.26)$. They also claimed that they always "intervene in the lesson only if a problem arises" ( $M=4.31)$, even though they maintained that they often "intervene in the teacher's teaching whenever I like" ( $M=4.10)$. Finally, participants stated that often during their observations, "The atmosphere becomes tense in the classroom" ( $M=3.83)$.

Table 8: Supervisors' perceptions of the supervision approach

\begin{tabular}{|c|c|c|}
\hline Item & Mean & Std. Deviation \\
\hline $\begin{array}{l}\text { Supervision creates fear and } \\
\text { stress in teachers.* }\end{array}$ & 2.76 & 1.03 \\
\hline $\begin{array}{l}\text { Supervision is done with the } \\
\text { aim of control, rather than } \\
\text { improvement.* }\end{array}$ & 2.76 & 1.09 \\
\hline $\begin{array}{l}\text { Supervision creates stress in } \\
\text { supervisors. }{ }^{*}\end{array}$ & 2.94 & 1.03 \\
\hline $\begin{array}{l}\text { Supervision includes sharing } \\
\text { mutual responsibilities and } \\
\text { participation between the } \\
\text { teacher and the supervisor. }\end{array}$ & 2.94 & 0.93 \\
\hline $\begin{array}{l}\text { Supervision is more or less } \\
\text { "looking for errors".* }\end{array}$ & 2.94 & 0.95 \\
\hline $\begin{array}{l}\text { Supervision creates fear and } \\
\text { stress in students.* }\end{array}$ & 2.97 & 0.88 \\
\hline $\begin{array}{l}\text { Supervision does not assess class } \\
\text { dynamics/interaction.* }\end{array}$ & 3.00 & 1.15 \\
\hline $\begin{array}{l}\text { Supervision does not focus } \\
\text { enough on the discourse that } \\
\text { takes place in the classroom (i.e. } \\
\text { focuses mostly on the teacher).* }\end{array}$ & 3.03 & 1.05 \\
\hline $\begin{array}{l}\text { Supervision is like a mentoring } \\
\text { relationship. }\end{array}$ & 3.18 & 1.04 \\
\hline $\begin{array}{l}\text { Supervision does not concern } \\
\text { itself with teacher-made tests. }\end{array}$ & 3.21 & 1.11 \\
\hline $\begin{array}{l}\text { Supervision does not establish } \\
\text { connections between different } \\
\text { observations.* }\end{array}$ & 3.21 & 0.96 \\
\hline $\begin{array}{l}\text { Supervision is top down: } \\
\text { instructions come from } \\
\text { supervisor to teacher.* }\end{array}$ & 3.21 & 0.96 \\
\hline Supervision is authoritarian* & 3.24 & 0.83 \\
\hline $\begin{array}{l}\text { Supervision does not concern } \\
\text { itself with extra-curricular } \\
\text { activities that can enhance } \\
\text { students' English language } \\
\text { learning.* }\end{array}$ & 3.30 & 1.06 \\
\hline $\begin{array}{l}\text { Supervision is inspection rather } \\
\text { than a collaborative process.* }\end{array}$ & 3.34 & 1.00 \\
\hline Supervision is democratic. & 3.36 & 0.78 \\
\hline Category Mean & 3.09 & 0.99 \\
\hline
\end{tabular}


Table 9: Contributions as a supervisor to the professional development of the teachers you supervise

\begin{tabular}{|c|c|c|}
\hline Item & Mean & Std. Deviation \\
\hline $\begin{array}{l}\text { I train teachers to create } \\
\text { supplementary materials that } \\
\text { assist them in teaching their } \\
\text { classes. }\end{array}$ & 2.85 & 1.31 \\
\hline $\begin{array}{l}\text { I train teachers on how to } \\
\text { motivate students to improve } \\
\text { their English language. }\end{array}$ & 2.89 & 1.21 \\
\hline $\begin{array}{l}\text { When giving feedback, I offer } \\
\text { teachers alternative English } \\
\text { teaching practices to improve } \\
\text { their teaching. }\end{array}$ & 3.03 & 1.29 \\
\hline $\begin{array}{l}\text { I encourage teachers to teach in } \\
\text { a way that is consistent with the } \\
\text { principles of reflective teaching. }\end{array}$ & 3.06 & 1.25 \\
\hline $\begin{array}{l}\text { Overall, I help teachers improve } \\
\text { in their profession. }\end{array}$ & 3.06 & 1.41 \\
\hline $\begin{array}{l}\text { I encourage teachers to attend } \\
\text { courses, workshops or sessions to } \\
\text { become better teachers. }\end{array}$ & 3.09 & 0.98 \\
\hline $\begin{array}{l}\text { I encourage teachers to work } \\
\text { together for effective teaching }\end{array}$ & 3.09 & 1.19 \\
\hline $\begin{array}{l}\text { I train teachers to think of } \\
\text { alternatives to solve problems } \\
\text { and tackle instructional } \\
\text { challenges relevant to their } \\
\text { contexts. }\end{array}$ & 3.12 & 1.39 \\
\hline $\begin{array}{l}\text { I provide teachers with resources } \\
\text { that can improve language } \\
\text { teaching (e.g. websites, tips for } \\
\text { teaching, and books). }\end{array}$ & 3.21 & 1.10 \\
\hline $\begin{array}{l}\text { I help teachers think critically } \\
\text { about their English teaching } \\
\text { practices. }\end{array}$ & 3.24 & 1.35 \\
\hline $\begin{array}{l}\text { I run courses for teachers to help } \\
\text { them acquire new knowledge } \\
\text { and to get more training in using } \\
\text { new teaching methods and } \\
\text { strategies. }\end{array}$ & 3.35 & 1.25 \\
\hline $\begin{array}{l}\text { I encourage teachers to reflect on } \\
\text { their teaching practices following } \\
\text { class observations. }\end{array}$ & 3.50 & 1.13 \\
\hline $\begin{array}{l}\text { I provide guidance to teachers on } \\
\text { how to improve their language } \\
\text { proficiency. }\end{array}$ & 3.91 & 0.79 \\
\hline $\begin{array}{l}\text { I provide guidance to teachers } \\
\text { related to English teaching. }\end{array}$ & 4.18 & 0.76 \\
\hline Category Mean & 3.25 & 1.17 \\
\hline
\end{tabular}

Supervisors maintained that they always engaged in five of the post-observation activities listed in Table 13. That is, they maintained that always, "The teacher and I meet to discuss the observed lesson immediately after the teacher finishes teaching the class" ( $\mathrm{M}=4.52)$, "I take into consideration the teacher's responses to my observations" ( $M=4.39$ ), and, "My discussion with the teacher leaves the teacher enthusiastic about teaching" ( $M=4.32$ ). Participants stated that always, "My report cites examples from the observed lesson to demonstrate my points" ( $M=4.48$ ) and, "My comments cause the teacher to feel defensive about his/her teaching" ( $M=$ 4.45). Supervisors also claim that they often "give the teacher a written report of the evaluation in a timely manner" ( $M=4.13$ ) and "encourage the teacher to respond to observations" ( $M=3.77$ ). They also stated that their comments are often "constructive" $(M=4.10)$ and "fair" ( $M=3.87)$. Finally, supervisors claimed that they sometimes "provide the teacher with feedback using concrete observational data" (M $=3.35)$ and that, "My discussion leaves the teacher encouraged to improve" ( $M=2.81)$.

\section{Discussion}

Participants were asked to complete a three-part, 13-category questionnaire that inquired about their perceptions of EFL supervision in Oman. The second part of the questionnaire explored participants' views of supervision across ten main areas. Overall, participants held decidedly neutral views of supervision. For example, participants only expressed overall levels of agreement, hence suggesting more positive attitudes, towards one questionnaire area - views on the effectiveness of supervision. Here, supervisors maintained that supervision has valid, written criteria, that it clearly defines the role of both supervisors and the supervisory process, and that it helps identify and solve major instructional problems by acknowledging teacher strengths. However, despite this, supervisors were more neutral about whether supervision evaluated and measured classroom activities fairly, whether it has trained them on using observation criteria, and whether it helps find solutions for instructional problems. In addition, supervisors also held mixed attitudes about whether supervision contributed to teachers' professional development. That is, they agreed that supervision did help teachers gain new knowledge and become aware of best practice in order to improve their teaching, and that it taught teachers how to motivate their students and provided teachers with educational leaderships and with training in using new teaching methodologies. However, despite these contributions to teachers' professional growth, supervisors were neutral about whether supervision helped teachers in problem-solving and professional growth, whether it 
encouraged them to become reflective practitioners, and whether it helped improve their morale, hence suggesting a lack of faith in the current supervision system to meet some of its intended purposes as posited by authors such as Pajak (1989). This finding also tends to contradict research which reports that generally supervisors are themselves more positive about supervision than has been observed here (see Kayaoglu, 2012).

Supervisors also held neutral attitudes about the qualities of their colleagues, and were unsure about whether their fellow supervisors were well-trained, co-operative, qualified, or even knew English well. Moreover, participants expressed neutral attitudes about the challenges they face, neither agreeing nor disagreeing about whether a large number of administrative and technical tasks, a lack of professional development opportunities, a lack of support from the ministry and/or directorate, and a lack of resources represented challenges for them. Exclusively neutral attitudes were also expressed by participants about their current views of supervision, opportunities for supervisors' professional development, and perceptions of the supervisory approach. For example, supervisors remained neutral about whether supervision was mostly for paperwork formalities, about whether it is necessary to maintain teaching quality, and about whether it is fair, adequate, useful, and inspiring. In relation to the opportunities for professional development, supervisors were neutral about whether they conducted research, received various forms of training such as workshops and presentations, and if they have the opportunity

Table 10: Supervisors' administrative role

\begin{tabular}{|l|c|c|}
\hline \multicolumn{1}{|c|}{ Item } & Mean & Std. Deviation \\
\hline $\begin{array}{l}\text { I contribute to penalizing } \\
\text { irresponsible teachers. }\end{array}$ & 2.74 & 1.33 \\
\hline $\begin{array}{l}\text { I contribute to rewarding } \\
\text { teachers with best practices. }\end{array}$ & 3.21 & 1.20 \\
\hline $\begin{array}{l}\text { I make sure that teaching } \\
\text { resources are available for } \\
\text { teachers. }\end{array}$ & 3.33 & 1.32 \\
\hline $\begin{array}{l}\text { I update the teacher with the } \\
\text { new regulations and criteria } \\
\text { established by the ministry/ } \\
\text { directorate. }\end{array}$ & 3.76 & 1.05 \\
\hline $\begin{array}{l}\text { Supervisors play a role in } \\
\text { teachers' recruitment. }\end{array}$ & 3.79 & 0.91 \\
\hline $\begin{array}{l}\text { I have multiple responsibilities, } \\
\text { which reduces my focus on } \\
\text { supervision's main functions. }\end{array}$ & 4.12 & 0.88 \\
\hline \begin{tabular}{l} 
Category Mean \\
\hline
\end{tabular} & 3.49 & 1.11 \\
\hline
\end{tabular}

to discuss challenges. Participants were neutral in response to all items associated with their perceptions of the supervision approach, and neither agreed nor disagreed about whether supervision creates fear and stress in teachers and students, about whether

Table 11: Supervisors' views about the supervision process prior to observation

\begin{tabular}{|l|c|c|}
\hline \multicolumn{1}{|c|}{ Item } & Mean & Std. Deviation \\
\hline $\begin{array}{l}\text { When the observation focuses on } \\
\text { a specific aspect of teaching (e.g., } \\
\text { class management, use of visual } \\
\text { aids, etc.), I tell the teacher what } \\
\text { the focus is. }\end{array}$ & 3.81 & 0.91 \\
\hline $\begin{array}{l}\text { I decide everything in relation to } \\
\text { the observation process on my } \\
\text { own. }\end{array}$ & 3.74 & 1.03 \\
\hline $\begin{array}{l}\text { I notify the teacher of the } \\
\text { observation criteria. }\end{array}$ & 3.10 & 0.94 \\
\hline $\begin{array}{l}\text { I inquire about the characteristics } \\
\text { of the class and the lesson to be } \\
\text { observed. }\end{array}$ & 3.03 & 1.14 \\
\hline $\begin{array}{l}\text { There is a set schedule for my } \\
\text { visits and observations. }\end{array}$ & 2.90 & 1.01 \\
\hline $\begin{array}{l}\text { I meet with the teacher to discuss } \\
\text { their professional concerns, } \\
\text { expectations and problems. }\end{array}$ & 2.90 & 1.08 \\
\hline $\begin{array}{l}\text { The teacher and I discuss the } \\
\text { lesson plan. }\end{array}$ & 2.83 & 1.05 \\
\hline $\begin{array}{l}\text { I inform the teacher about the } \\
\text { purpose of the observation (i.e. } \\
\text { evaluation, promotion, etc.). }\end{array}$ & 2.74 & \\
\hline \\
\hline
\end{tabular}

Table 12: Supervisors' views about the observation process during supervision

\begin{tabular}{|l|c|c|}
\hline \multicolumn{1}{|c|}{ Item } & Mean & Std. Deviation \\
\hline $\begin{array}{l}\text { The observation duration is } \\
\text { adequate to assess the teacher's } \\
\text { performance fairly. }\end{array}$ & 4.45 & 0.85 \\
\hline $\begin{array}{l}\text { I participate in the lesson I } \\
\text { observe in a collegial manner. }\end{array}$ & 4.35 & 0.88 \\
\hline $\begin{array}{l}\text { My presence in the classroom as } \\
\text { an observer worries the teacher. }\end{array}$ & 4.32 & 0.79 \\
\hline $\begin{array}{l}\text { I fill out an observation form. } \\
\text { I intervene in the lesson only if a } \\
\text { problem arises. }\end{array}$ & 4.32 & 1.14 \\
\hline $\begin{array}{l}\text { I take notes to document the } \\
\text { observation for subsequent } \\
\text { discussion. }\end{array}$ & 4.31 & 0.81 \\
\hline $\begin{array}{l}\text { I sit at the back and do not } \\
\text { intervene in the lesson at all. }\end{array}$ & 4.26 & 1.13 \\
\hline $\begin{array}{l}\text { I intervene in the teacher's } \\
\text { teaching whenever I like. }\end{array}$ & 4.10 & 0.86 \\
\hline $\begin{array}{l}\text { The atmosphere becomes tense } \\
\text { in the classroom. }\end{array}$ & 3.83 & 1.22 \\
\hline $\begin{array}{l}\text { Category Mean } \\
\text { Ih }\end{array}$ & 4.24 & 0.99 \\
\hline
\end{tabular}


Table 13: Supervisors' views about the observation process after supervision

\begin{tabular}{|c|c|c|}
\hline Item & Mean & Std. Deviation \\
\hline $\begin{array}{l}\text { The teacher and I meet to discuss } \\
\text { the observed lesson immediately } \\
\text { after the teacher finishes } \\
\text { teaching the class. }\end{array}$ & 4.52 & 0.93 \\
\hline $\begin{array}{l}\text { My report cites examples } \\
\text { from the observed lesson to } \\
\text { demonstrate my points. }\end{array}$ & 4.48 & 0.93 \\
\hline $\begin{array}{l}\text { My comments cause the teacher } \\
\text { to feel defensive about his/her } \\
\text { teaching. }\end{array}$ & 4.45 & 0.83 \\
\hline $\begin{array}{l}\text { I take into consideration the } \\
\text { teacher's responses to my } \\
\text { observations. }\end{array}$ & 4.39 & 0.76 \\
\hline $\begin{array}{l}\text { My discussion with the teacher } \\
\text { leaves the teacher enthusiastic } \\
\text { about teaching. }\end{array}$ & 4.32 & 1.08 \\
\hline $\begin{array}{l}\text { I give the teacher a written report } \\
\text { of the evaluation in a timely } \\
\text { manner. }\end{array}$ & 4.13 & 0.76 \\
\hline My comments are constructive. & 4.10 & 1.01 \\
\hline My comments are fair. & 3.87 & 0.76 \\
\hline $\begin{array}{l}\text { I encourage the teacher to } \\
\text { respond to observations. }\end{array}$ & 3.77 & 1.09 \\
\hline $\begin{array}{l}\text { I provide the teacher with } \\
\text { feedback using concrete } \\
\text { observational data. }\end{array}$ & 3.35 & 0.66 \\
\hline $\begin{array}{l}\text { My discussion leaves the teacher } \\
\text { encouraged to improve. }\end{array}$ & 2.81 & 1.38 \\
\hline Category Mean & 4.01 & 0.92 \\
\hline
\end{tabular}

it is democratic or authoritarian, and about whether it is more concerned with looking for errors than focusing on discourse and links between lessons in a collaborative teacher-supervisor process.

While such findings might suggest that supervisors are unwilling to identify the current supervision process as either positive or negative, they did express disagreement, and hence more negative attitudes, towards a number of items associated with the supervisors' professional role, the contribution they make to teachers' professional development, and their administrative role. For example, in relation to this first area, supervisors disagreed that they respond to teachers' instructional concerns, that they ensure senior teachers are doing their jobs properly, and that they train teachers in creating a portfolio to demonstrate their professional development. They also disagreed about the contributions they make to the professional development of their teachers, about whether they encourage teachers to reflect on teaching practice, whether they provided guidelines for teachers to improve their language proficiency, and whether they offer guidance related to English teaching. Finally, in terms of their administrative role, supervisors disagreed that they receive updates from the ministry and/or directorate about new regulations and criteria and about whether they are involved in teacher recruitment. These findings are somewhat of a concern given Ilin, Inozu, and Yildirim's (2007) contention that good supervisors are cooperative, supportive, encourage reflective thinking among their teachers, and establish good rapport with them. Findings from this part of the questionnaire, therefore, indicate a rather mixed view of the supervision process with participants unlikely to identify many good aspects of supervision though remaining far more likely to indicate either neutral or negative attitudes.

The next questionnaire section concerned the frequency with which participants engaged in a series of steps before, during, and after supervising a teacher. Supervisors claimed that they only sometimes set a schedule for their visits and observations, that they often focus on a specific aspect of teaching and that they often decide everything in relation to the observation process on their own without teacher collaboration. Supervisors also stated that they sometimes discussed lesson plans together with the supervised teacher before the lesson and encouraged teachers to express their professional concerns. During the lesson, supervisors stated that they always observe the class for an adequate period of time, that they always take notes at the back of the class and complete the forms in a timely manner, and that they always observe in a collegial manner and only intervene if there is a problem. However, supervisors noted that the atmosphere in the class often becomes tense due to their presence. Moreover, in relation to post-observation process, supervisors claimed that they always meet with the teachers to discuss the observed lesson immediately, that they always take into account teachers' responses to their observations, and that their discussion always leaves the teacher feeling more enthusiastic about teaching. It should be noted that supervisors maintain that teachers only sometimes take account of their post-observation feedback which is often posited as an essential part of the observation process (Buskist, Ismail, \& Groccia, 2014).

\section{Conclusion}

This study was based on concerns about the 
effectiveness of the current supervision system for English teachers in Omani government schools. Findings suggest that supervisors are generally either neutral or even negative about the supervisory system. This is an interesting outcome in that it largely goes against findings in the literature which suggest that it is usually supervisors themselves which hold the most positive attitudes towards supervision (see Kayaoglu, 2012). Supervisors here only showed mildly positive attitudes in a small number of areas although one of these did, of course, concern the effectiveness of supervision. That is, participants largely maintained that they help teachers to develop as professionals even though, contrary to Ilin, Inozu, and Yildirim's (2007) characterization of good supervision, they claim that they largely do not encourage teacher reflection nor provide guidance for improving teachers' language proficiency and English teaching pedagogy.

Perhaps more importantly, however, were supervisors, somewhat neutral views of their fellow supervisors, including a lack of agreement about whether their colleagues were well-trained, cooperarative, perform their work professionally, or even spoke English well. Combined with concerns about the lack of agreement supervisors offered about the effectiveness of the supervisory system, including whether supervision is based on valid criteria, helps solve instructional problems, helps teachers to identify areas that they need to work on, and offers teachers constructive feedback, this apparent lack of faith in the ability, or even dedication, of fellow supervisors suggests a lack of morale among supervisors and may suggest a need for a thorough review of the current system. This belief could be argued to be supported by supervisors' neutrality about whether the teachers they supervise attempt to integrate their post-observation feedback and whether supervision was done primarily for the purpose of completing paperwork.

Of course, as offered above, the overriding degree of neutrality expressed here may not actually be an expression of a lack of faith in the supervisory process, but may be a result of a rift between those participants who hold mostly positive attitudes towards supervision and those who hold predominantly negative ones a situation that could be argued to be witnessed in the rather large standard deviations reported across questionnaire categories. This is a supposition that could be explored in greater detail in further research that seeks to move beyond the questionnaire design utilized here and incorporates, for example, interviews with supervisors and the teachers they supervise, observations and so on. Moreover, the low level of internal consistency of the questionnaire category related to participants' contributions as supervisors to the professional development of supervised teachers, must also be taken into account.

However, for now, it is perhaps possible to argue that the supervisory process does not enjoy the full support of the people who are employed to implement it. This could be a result of the system's shortcomings, a lack of morale among supervisors, or even other professional and/or societal factors that have not been explored here. However, if this is the case, then it is important that the supervisory system be examined in-depth and that all attempts are made to make it as equitable, practical, and effective as possible.

\section{References}

Al-Abri, O. M. (2009). Supervisors' perception of the supervisory process. In S. Borg (Ed.), Researching English language teaching and teacher development in Oman (pp. 81-89). Muscat: Ministry of Education.

Al-Jardani, K. S. (2012). English language curriculum evaluation in Oman. International Journal of English Linguistics, 2(5), 40-44.

Al-Mahrooqi, R., Al-Maamari, F., \& Denman, C. J. (2015). Public school graduates and their weakness in English: Stakeholder perspectives. Unpublished research report, Sultan Qaboos University, Oman.

Al-Mahrooqi, R., \& Denman, C. J. (2017). Oman public school supervisor evaluations of English communication in EFL classrooms. Proceedings of Pedagogia 2017 (pp. 1040-1049). Havana, Cuba: Ministry of Education.

Al-Mahrooqi, R., Denman, C. J., \& Al-Maamari, F. (2016). Omani supervisor perspectives of contextual factors impacting upon students' limited English proficiency: An exploratory study. International Journal for 21st Century Education, 3(1), 59-68.

Barber, M., Mourshed, M., \& Whelan, F. (2007). Improving education in the Gulf. The McKinsey Quarterly, Special Edition: Reappraising the Gulf States, 39-47.

Buskist, W., Ismail, E. A., \& Groccia, J. E. (2014). A practical model for conducting helpful peer review of teaching. In J. Sachs \& M. Parsell (Eds.), Peer review of 
learning and teaching in higher education (pp. 33-52). London: Springer.

Chapman, D., Al Barwani, T., \& Hana, A. (2009). Private higher education in Oman: The dilemma of quality. Paper presented at the annual meeting of the 53rd Annual Conference of the Comparative and International Education Society, South Carolina, USA.

Ilin, G., Inozu, J., \& Yildirim, R. (2007). Successful supervision from student-teachers' perspective: An analysis of supervisory talk. Hacettepe Üniversitesi Eğitim Fakültesi Dergisi, 32, 123-132.

Kayaoglu, M. N. (2012). Dictating or facilitating: The supervisory process for language teachers. Australian Journal of Teacher Education, 37(10). 103-117. doi. org/10.14221/ajte.2012v37n10.4

Ministry of Education. (2001). Basic Education in the Sultanate of Oman: The theoretical framework. Muscat: Ministry of Education, Sultanate of Oman.

Ministry of Education. (2006). From access to success: Education for all (EFA) in the Sultanate of Oman 19702005. Muscat: author.

Ministry of Education and the World Bank. (2012). Education in Oman: The drive for quality. Muscat: author.

Pajak, E. (1989). Identification of supervisory proficiencies. Alexandria, VA: Association for Supervision and Curriculum Development.

UNISCO. (2011). World data on education (7th ed.). Retrieved from http://www.ibe.unesco.org/ fileadmin/user_upload/Publications/WDE/2010/pdfversions/Oman.pdf 